\title{
BASELINE WIDAL TITRES AMONG APPARENTLY HEALTHY INDIVIDUALS IN HADOTI REGION, RAJASTHAN
}

Naveen Saxena, Deepak Maheshwari, Divya Dadhich

1. Associate Professor. Department of Microbiology, Government Medical College, Kota.

2. Post Graduate Resident. Department of Microbiology, Government Medical College, Kota.

3. Post Graduate Resident. Department of Microbiology, Government Medical College, Kota.

\section{CORRESPONDING AUTHOR:}

Dr. Naveen Saxena,

Department of Microbiology,

Government Medical College, Kota.

E-mail: drnaveen_saxena@yahoo.co.in

ABSTRACT: AIM AND OBJECTIVE: The interpretation of the Widal test depends upon the baseline titre among healthy individuals in a particular geographical area. This study was undertaken to determine the baseline Widal titre in apparently healthy individuals in, Hadoti region, Rajasthan. MATERIALS AND METHODS: Blood samples were collected from healthy blood donors $(n=200)$ who attended blood bank of this institution from May 2012 to August 2012. The Widal tube agglutination test was carried out. $0.5 \mathrm{ml}$ of two fold serially diluted patients' sera (dilutions from 1:20 to $1: 160$ ) in $0.9 \%$ normal saline was tested by adding an equal amount of antigen. RESULTS: Of the 200 serum samples which were tested, 108 serum samples were positive for agglutinins against Salmonella serotypes $(\geq 1: 20)$ and 92 serum samples were negative for agglutinins. Among 54 samples with an anti-0 titer $(\geq 1: 20), 39$ samples had titres of 1:40. Among the 63 samples demonstrating anti-H titres of $\geq 1: 20$ to salmonella serotype, 48 had a titer of 1:40. For salmonella Paratyphi A and B, anti-H titres of 1:20 were found in $3 \%$ and $1.5 \%$, respectively, of all samples tested. CONCLUSION: We recommended that the significant titre of the ' $\mathrm{H}$ ' agglutinin and the ' $\mathrm{O}$ ' agglutinin of Salmonella Typhi is $\geq 1: 80$. While the significant titre of the ' $\mathrm{H}$ ' agglutinins of Salmonella Paratyphi $A$ and Salmonella Paratyphi B is $\geq 1: 40$.

KEYWORDS: Typhoid Fever, Base line titre, Widal test

INTRODUCTION: Enteric fever is an acute, life-threatening febrile illness caused by the bacterium Salmonella serotype Typhi. Paratyphoid fever is a similar illness caused by Salmonella serotype Paratyphi A, B, or C.(1,2) Enteric fever (typhoid and paratyphoid) is a major public health problem in most developing countries.(3) Definitive diagnosis of enteric fever depends on isolation of Salmonella from blood, stool, urine, bone marrow, bile or other body fluids.(4) However, in developing countries, culture facilities are not available everywhere. For these reasons, laboratory diagnosis of enteric fever relies heavily on serological tests such as the Widal test. Widal agglutination test is a widely used serological test for diagnosis of enteric fever in developing countries. Widal test utilizes a suspension of killed Salmonella serotypes as antigen to detect antibodies in serum of patients with suspected enteric fever.(5) The test is based on demonstration of the presence of agglutinin (antibody) in the serum of an infected patient, against the $\mathrm{H}$ (flagellar) and $\mathrm{O}$ (somatic) antigens of Salmonella serotype Typhi, Paratyphi A and Paratyphi B during the acute and convalescent period of infection.(6) Usually up to $70 \%$ of adults show an early rise of antibody titre in the first week of infection.(3) Antibody titre may be high in healthy individuals in the presence of cross reacting antigens, 
such as malaria, brucellosis, dengue fever, healthy carrier state, chronic liver disease, endocarditis or other Enterobacteriaceae infections, vaccination with typhoid vaccine.(7) So Serological diagnosis relies classically on the demonstration of a rising titre of antibodies in paired samples 10 to 14 days apart. In typhoid fever, however, such a rise is not always demonstrable, even in blood culture-confirmed cases.(8) This situation may occur because the acute-phase sample was obtained late in the natural history of the disease, because of high levels of background antibodies in a region of endemicity, or because in some individuals the antibody response is blunted by the early administration of an antibiotic.(3) Furthermore, patient management cannot wait for results obtained with a convalescent-phase sample. For practical purposes, a treatment decision must be made on the basis of the results obtained with a single acute-phase sample.(9) Thus the interpretation of the Widal test depends upon the baseline titre among healthy individuals in a particular geographical area.(10) In a given population, interpretation of a single Widal test result needs to be based on average baseline titre among the healthy individuals. Antibody titres beyond a cut off value should be regarded as significantly elevated titres which may be used for diagnosis in an appropriate clinical setting.

MATERIAL AND METHOD: After taking ethical clearance from institute committee this study was conducted in the Department of Microbiology at Central Laboratory of MBS Hospital attached to Government Medical College, Kota (Rajasthan). After informed consent blood samples were collected from healthy blood donors $(n=200)$ who attended blood bank of this institution from May 2012 to August 2012.

Selection of samples: The blood donors were screened using survey questionnaire. Blood samples were collected from apparently healthy donors, who had neither been vaccinated with TAB vaccine within last year nor had suffered from any type of fever in last 6 months. Individuals with any active or recent infections including hepatitis $B$, hepatitis $C$, enteric fever, malaria or HIV/AIDS were also excluded from the study.

Collection and preservation of blood samples: $5 \mathrm{ml}$ of venous blood was collected in a plain vial with help of syringe. It was allowed to clot at room temperature for about 30-60 minutes. Then the samples were centrifuged at a high speed for 5 minutes in order to separate the serum from the blood. Serum was transferred in clean, dry, sterile vials.

Reagents: Stained salmonella antigens test kit for tube test (SPAN Diagnostic private limited, INDIA), containing smooth suspension of Salmonella serotype Typhi "H", Salmonella serotype Typhi "O", Salmonella serotype Paratyphi "AH" and Salmonella serotype Paratyphi "BH" antigens were used.

PROCEDURE: Widal titre was estimated by confirmatory quantitative tube agglutination test using standard agglutination test procedure.(5) Briefly, $0.5 \mathrm{ml}$ of the 2 fold serially diluted sera (dilutions from 1:20 to 1:160) in 0.9\% normal saline were tested by adding an equal amount of antigen and the tubes were than incubated overnight at $37^{\circ} \mathrm{C}$ in a water bath. A negative control was included in each batch of the tests. The tubes were mixed well and incubated in serological water bath maintained at $37 \stackrel{\circ}{\mathrm{C}}$ for 16 - 20 hours and observed for agglutination. 0 Antigen showed granular agglutination and $\mathrm{H}$ Antigen showed fluffy agglutination. The last tube 
showing visible agglutination with naked eye was taken as endpoint of the test. The titre was reported out as the reciprocal of the end point.

RESULTS: Out of 200 serum samples, 108 (54\%) serum samples were positive for one or more type of agglutinins $(\geq 1: 20)$ and $92(46 \%)$ serum samples were negative for agglutinins $(<1: 20)$ [Table 1]. The distribution of the samples with an antibody titre of $\geq 1: 20$ against different serotypes of Salmonella showed an antibody to the anti 0 antigen in $54(27 \%)$ samples, anti $\mathrm{H}$ antigen in $63(31.5 \%)$ samples, anti AH antigen in 07 (3.5\%) samples and anti BH antigen in 03 (1.5\%) samples [Table 2]. Among the 54 samples showing reactivity to 0 antigen, 39 samples $(19.5 \%)$ showed a titre of 1:40 [Table 3]. Among the 63 positive samples with anti $\mathrm{H}$ titre against Salmonella serotype Typhi, a titre of 1:40 was seen in 48 samples (24\%) [Table 4]. The agglutinating titre of 1:40 for the AH titre against Salmonella serotype Paratyphi A was seen only in one sample $(0.5 \%)$, while none of the sample against Salmonella serotype Paratyphi B showed reactivity to a titre of $1: 40$ [Table 5].

DISCUSSION: Although the Widal test is widely used in Hadoti region of Rajasthan for the diagnosis of enteric fever, yet no previous attempts were made to find out the baseline Widal titre amongst the local population as per our knowledge. So the purpose of this study was to determine the average baseline antibody titre for the interpretation of the Widal test results. Definitive laboratory diagnosis of enteric fever depends upon isolation of causal organism by culture, but culture facilities are not available everywhere. Also, the lack of proper specimen management decreases the positivity of culture. So the Widal agglutination test is used as an alternative laboratory procedure for diagnosis of enteric fever. The results of this study showed that the sera of a significant proportion of healthy individuals in this area contained antibodies which were capable of reacting to the variable titres in the Widal test. Among the 200 blood samples of healthy blood donors who were tested, 108 (54\%) were positive for agglutinins for the Salmonella serotypes. In acute typhoid fever, a rise in the anti 0 antibody titre followed by a gradual elevation of anti $\mathrm{H}$ antibody titre occurs. The anti $\mathrm{H}$ antibody response persists longer than the anti 0 antibody. We found that $27 \%$ of samples were reactive for anti 0 titre and $31.5 \%$ for anti $\mathrm{H}$ titre of Salmonella serotype Typhi. The highest level of the Widal titre was found to be 1:160 for the $\mathrm{O}$ and $\mathrm{H}$ antigen of Salmonella serotype Typhi. However, highest percentage of samples $(19.5 \%$ for the 0 antigen and $24 \%$ for the $\mathrm{H}$ antigen of Salmonella serotype Typhi) showed a titre of 1:40. Thus the baseline titre for the $\mathrm{O}$ and $\mathrm{H}$ antibodies of $\mathrm{S}$. typhi was assumed to be 1:40. Similarly the baseline titre for the $\mathrm{H}$ antigen of Salmonella serotype Paratyphi A and Salmonella Paratyphi B was found to be 1:20. Our findings were in accordance to the reports of previous study done by Punia JN in Chandigarh [Table 6].(10) A single Widal test in an endemic area is of no diagnostic value unless carefully interpreted based on the local baseline titre, as the level of titres detectable in normal population of different areas vary considerably.(9) So, each region should have a baseline titre of their healthy population, which should be updated with time.(11)

CONCLUSION: Widal test results in acute phase serum sample should be interpreted based on prevalent baseline titre in that particular geographic area. In this study $19.5 \%$ samples for the 0 antigen and $24 \%$ samples for the $H$ antigen of Salmonella serotype Typhi showed a titre of 1:40. Thus the baseline titre for the $\mathrm{O}$ and $\mathrm{H}$ antibodies of Salmonella serotype Typhi was assumed to be 1:40. Similarly the baseline titre for the $\mathrm{H}$ antigen of Salmonella serotype Paratyphi $\mathrm{A}$ and 
Salmonella Paratyphi B was found to be 1:20. Based on the results of this study we recommended that the significant titre of the $\mathrm{O}$ agglutinin and the $\mathrm{H}$ agglutinin of Salmonella Typhi is $\geq 1$ : 80 . While the significant titre of the $\mathrm{H}$ agglutinin of Salmonella Paratyphi A and Salmonella Paratyphi B is $\geq 1: 40$ in Hadoti region of Rajasthan.

Table 1- Results of Widal test

\begin{tabular}{|l|l|l|}
\hline Widal status & Frequency & Percentage \\
\hline Total sample & 200 & 100 \\
\hline $\begin{array}{l}\text { Positive for agglutinin } \quad(\geq \\
1: 20)\end{array}$ & 108 & 54 \\
\hline $\begin{array}{l}\text { Negative for agglutinin } \quad< \\
1: 20)\end{array}$ & 92 & 46 \\
\hline
\end{tabular}

Table 2- Distribution of the positive samples $(\mathrm{n}=108)$ with antibody titre $\geq 1: 20$ against different serotypes of Salmonella.

\begin{tabular}{|l|l|l|}
\hline Serotype & Antibody type & Frequency \\
\hline S. Typhi & Anti-O antigen & $54(27 \%)$ \\
\hline S. Typhi & Anti-H antigen & $63(31.5 \%)$ \\
\hline S. Paratyphi A & Anti-AH antigen & $07(3.5 \%)$ \\
\hline S. Paratyphi B & Anti-BH antigen & $03(1.5 \%)$ \\
\hline
\end{tabular}

Table 3- Distribution of 54 samples with anti 0 titre $\geq 1: 20$ against Salmonella serotype Typhi.

\begin{tabular}{|l|l|l|}
\hline Agglutinating titre & Frequency & Percentage \\
\hline TO $-1: 20$ & 12 & 6 \\
\hline TO $-1: 40$ & 39 & 19.5 \\
\hline TO $-1: 80$ & 2 & 1 \\
\hline TO $-1: 160$ & 1 & 0.5 \\
\hline
\end{tabular}

Table 4- Distribution of 63 samples with anti $H$ titre $\geq 1: 20$ against Salmonella serotype Typhi

\begin{tabular}{|l|l|l|}
\hline Agglutinating titre & $\begin{array}{l}\text { Frequenc } \\
\mathbf{y}\end{array}$ & Percentage \\
\hline TH $-1: 20$ & 07 & 3.5 \\
\hline TH $-1: 40$ & 48 & 24 \\
\hline TH $-1: 80$ & 05 & 2.5 \\
\hline TH $-1: 160$ & 03 & 1.5 \\
\hline
\end{tabular}

Table 5-Distribution of 07 samples with anti AH titre $\geq 1: 20$ and 03 samples with anti BH titre $\geq 1: 20$ against Salmonella serotype Paratyphi A and B.

\begin{tabular}{|l|l|l|}
\hline $\begin{array}{l}\text { Agglutinating } \\
\text { titre }\end{array}$ & Frequency & Percentage \\
\hline $\mathrm{AH}-1: 20$ & 06 & 3 \\
\hline $\mathrm{AH}-1: 40$ & 01 & 0.5 \\
\hline $\mathrm{BH}-1: 20$ & 03 & 1.5 \\
\hline $\mathrm{BH}-1: 40$ & 0 & 0 \\
\hline
\end{tabular}


Table 6- Comparative analysis of Baseline titre of $\mathrm{O}$ and $\mathrm{H}$ agglutinins in different regions of India

\begin{tabular}{|l|l|l|l|l|l|l|}
\hline Shukla S et al.(12) & Central India & 1997 & $1: 80$ & $1: 80$ & 0 & 0 \\
\hline Punia JM et al.(10) & Chandigarh & 2003 & $1: 80$ & $1: 160$ & $1: 20$ & $1: 20$ \\
\hline Patil Anand M et al.(13) & Karnataka $\quad$ In 2007 & $1: 80$ & $1: 80$ & $1: 40$ & $1: 40$ \\
\hline Present study & Hadoti region (Raj.) & 2012 & $1: 40$ & $1: 40$ & $1: 20$ & $1: 20$ \\
\hline
\end{tabular}

\section{REFERENCE:}

1. Ananthanarayan R, Paniker CKJ. No Title. Textbook of Microbiology. Hyderabad, Orient Longman; 2003;275-6.

2. Parker MT, Collier LH. No Title. Topley \& Wilson's Principle of bacteriology, Virology \& Immunology. London, Edward Arnold; 1990;487.

3. Chessbrough M. No Title. Medical Laboratory Manual for Tropical Countries. Cambridge, ELBS; 1987;260-1.

4. Gilman RH, Terminel M, Levine, Hernandez-Mendoza P, Hornick RB. Relative efficacy of blood, urine, rectal swab, bone marrow, and rose spot cultures for recovery of Salmonella typhi in typhoid fever. Lancet. 1975;31;1(7918):1211-3.

5. Cruickshank R. No Title. Medical Microbiology. London, Churchill Livingston; 1982;403.

6. Washington JA, Henry JB. No Title. Medical microbiology in clinical diagnosis and management by laboratory methods. Philadelphia, WB Saunders; 1984;1102.

7. Colle JG, Frason AG, Marmion BP, Simmons A. No Title. Mackie and Mc Cartney Practical Medical Microboiology. New York, Churchill Livingston; 1996;389.

8. Parry CM, Wijedoru L. The utility of diagnostic tests for enteric fever in endemic locations. 2011;711-25.

9. Pokhrel BM, Karmacharya R, Mishra SK, Koirala J. Distribution of antibody titer against Salmonella enteric among healthy individuals in Nepal. Ann Clin Microbiol Antimicrob. 2009;7:1-8.

10. Punia JN, Joshi RM, Gupta V, Arora RK. Determination of baseline widal titers from Chandigarh. Indian J Med Microbiol. 2003;21:144.

11. Hoa NTT, Diep TS, Wain J, Parry CM, Hien TT, Smith MD, et al. Community-acquired septicaemia in an infectious diseases hospital in Viet Nam. The importance of multi-drug resistant. Salmonella typhi. 1998;92(5):503-8.

12. Shukla, S., B. Patel and DSC. 100 years of Widal test and its reappraisal in an endemic area. Indian Med. Res. 1997;(105):53-57.

13. Patil AM, Kulkarni ML, Kulkarni AM. Baseline Widal titres in healthy children [Internet]. The Indian Journal of Pediatrics. Department of Pediatrics, J.J.M. Medical College, 2373, 9th MAIN, MCC “A” Block, Davangere, 577 004, Karnataka State, India; 2008. Available from: http://dx.doi.org/10.1007/s12098-007-0201-0 